\title{
ANALISIS KELAYAKAN INVESTASI PENGGEMUKAN SAPI POTONG (KASUS: PT CATUR MITRA TARUMA, KABUPATEN BOGOR)
}

\author{
Chairun Nisa ${ }^{1)}$, Ratna Winandi ${ }^{2)}$ dan Netti Tinaprilla ${ }^{3)}$ \\ 1,2,3)Departemen Agribisnis, Fakultas Ekonomi dan Manajemen,Institut Pertanian Bogor \\ ${ }^{1)}$ cnsbasymeleh@gmail.com
}

\begin{abstract}
A gap between national beef consumption and beef production becomes an opportunity for beef cattle fattening business. . The purpose of this research is to analyze the feasibility of beef cattle fattening. The research was conducted at the main office of PT Catur Mitra Taruma at South Jakarta and its feedlot stall at Desa Cariu, Kabupaten Bogor. Aqualitative analysis method was used to analyze the non-financial feasibility, that covered market aspects, technical aspects, management and law aspects, and also social, economic, and environmental aspects. The financial feasibility was analyzed quantitatively by investment criteria and switching value analysis. The result shows that beef cattle fattening in PT Catur Mitra Taruma is feasibleand it is more sensitive to the decreasing sales of beef cattle than to the increasing price of feed.
\end{abstract}

Keyword(s): beef cattle, fattening, feasibility.

\begin{abstract}
ABSTRAK
Terdapat kesenjangan antara jumlah konsumsi daging sapi dengan jumlah produksi daging sapi nasional. Kesenjangan tersebut membuka peluang untuk bisnis penggemukan sapi potong. Tujuan dari penelitian ini adalah untuk menganalisis kelayakan investasi penggemukan sapi potong, dengan mengambil contoh kasus pada PT Catur Mitra Taruma. Lokasi penelitian dilakukan di kantor pusat PT Catur Mitra Taruma di Jakarta Selatan dan di lokasi kandang penggemukan di Desa Cariu Kabupaten Bogor. Metode analisis yang digunakan dalam penelitian ini adalah analisis kualitatif dan kuantitatif. Analisis kualitatif digunakan untuk menilai kelayakan investasi berdasarkan aspek nonfinansial meliputi aspek pasar, aspek teknis, aspek manajemen dan hukum, dan aspek sosial, ekonomi, dan lingkungan. Sedangkan analisis kuantitatif digunakan untuk menilai kelayakan investasi berdasarkan kriteria penilaian investasi meliputi NPV, Net B/C, IRR, dan Payback Period. Selain itu juga dilakukan analisis sensitivitas berdasarkan switching value. Hasil analisis yang diperoleh, bisnis penggemukan sapi potong pada PT Catur Mitra Taruma layak untuk dijalankan baik berdasarkan aspek nonfinansial maupun aspek finansial. Selain itu, bisnis penggemukan sapi potong pada PT Catur Mitra Taruma lebih peka terhadap penurunan volume penjualan sapi potong dibandingkan peningkatan harga pakan.
\end{abstract}

Kata Kunci: kelayakan, penggemukan, sapi potong.

PENDAHULUAN

Subsektor peternakan merupakan salah satu bagian dari sektor pertanian yang menyumbang pertumbuhan perekonomian nasional, dibuktikan dengan laju pertumbuhan yang selalu bernilai 
positif dan kontribusi yang cenderung meningkat (Ditjennak, 2013). Sapi potong merupakan sumber penyedia daging terbesar kedua di Indonesia setelah ayam (Ngadiyono, 2004; BKPM, 2012). Daging sapi merupakan salah satu komoditas prioritas dalam pembangunan ketahanan pangan nasional, terutama ketahanan pangan asal ternak (Saragih, 2000; Daryanto, 2009; Priyanti, et al. 2011). Selain mengandung gizi yang tinggi, daging sapi juga memiliki nilai ekonomis yang tinggi. Daging sapi merupakan komoditas peternakan yang bersifat high income elastic. Artinya, dengan semakin meningkatnya pendapatan maka akan diikuti dengan meningkatnya permintaan terhadap daging sapi (Saragih, 2000; Ilham, 2009).

Terdapat dua pelaku utama dalam industri sapi potong di Indonesia yaitu peternak rakyat dan perusahaan berbadan hukum (swasta dan BUMN). Perbedaan di antara keduanya terletak pada skala usaha, permodalan, dan pemeliharaan. Peternak rakyat umumnya memiliki skala usaha relatif kecil, permodalan terbatas, sistem pemeliharaan tradisional dalam bentuk usaha pembibitan maupun penggemukan (Hadi dan Ilham, 2002; Suryana, 2009; Sunari et al., 2010; Ekowati et al., 2011; Ashari et al., 2012; Prasetyo et al., 2012). Sementara itu, perusahaan berbadan hukum umumnya memiliki skala usaha yang relatif besar, padat modal, dan sistem pemeliharaan lebih modern dalam bentuk usaha pembibitan dan penggemukan. Namun, umumnya usaha pembibitan kurang diminati perusahaan swasta karena efisiensinya rendah dan jangka pengem- balian modal panjang (Suryana, 2009; Priyanto, 2011).

Perkembangan industri penggemukan sapi potong di Indonesia didukung oleh berbagai faktor, di antaranya faktor harga, peningkatan kebutuhan, dan kebijakan pemerintah. Harga daging sapi, baik di tingkat produsen maupun konsumen tercatat mengalami peningkatan dari tahun ke tahun. Data yang dikeluarkan Pusdatin (2013a) menunjukkan bahwa terjadi peningkatan sebesar 8,23 persen pada rata-rata harga produsen daging sapi dan peningkatan sebesar 8,92 persen pada rata-rata harga konsumen daging sapi di seluruh Indonesia pada periode 20082013. Tren positif harga daging sapi tersebut menjadi peluang bagi berkembangnya bisnis penggemukan sapi potong.

Peningkatan kebutuhan daging sapi masyarakat Indonesia juga menjadi salah satu peluang berkembangnya bisnis penggemukan sapi potong di Indonesia. Kebutuhan daging sapi masyarakat Indonesia terus meningkat seiring dengan peningkatan jumlah penduduk, peningkatan daya beli masyarakat, dan perubahan gaya hidup serta peningkatan kesadaran akan pentingnya pemenuhan gizi yang seimbang (Daryanto, 2009; Mayulu, et al. 2010). Rata-rata konsumsi daging sapi per kapita masyarakat Indonesia antara tahun 2002-2012 sebesar 1,87 kg/kapita/tahun, dengan rata-rata peningkatan sebesar 3,23 persen setiap tahunnya (Pusdatin, 2013b).

Upaya pemenuhan kebutuhan daging sapi terus diupayakan oleh pemerintah maupun oleh pihak swasta 
yang menjalankan usaha peternakan sapi potong. Hal ini ditunjukkan oleh jumlah populasi sapi potong dan produksi daging sapi yang terus meningkat setiap tahunnya, dengan masing-masing peningkatan berturut-turut sebesar 6,83 persen dan 7,48 persen setiap tahunnya (Ditjennak, 2013).

Peningkatan populasi dan produksi daging sapi yang terjadi pada kenyataannya belum mampu memenuhi seluruh kebutuhan dalam negeri, baik itu kebutuhan pelaku usaha maupun kebutuhan konsumen akhir. Hal tersebut dibuktikan dengan masih dibukanya impor sapi hidup maupun daging sapi oleh pemerintah. Bahkan pada tahun 2013 pemerintah melalui Kementerian Perdagangan mengeluarkan Permendag Nomor 46/M-DAG/PER/8/2013 tentang Ketentuan Impor dan Ekspor Hewan dan Produk Hewan yang menghapuskan sistem kuota impor dan digantikan dengan mekanisme harga referensi (Kemendag, 2013). Penghapusan kuota impor dan pembebasan importasi sapi potong melalui Permendag tersebut menjadi peluang tersediri bagi berkembangnya bisnis penggemukan sapi potong di Indonesia.

Peluang-peluang yang muncul baik dari sisi harga, peningkatan kebutuhan, dan kebijakan pemerintah dapat mendorong berkembangnya bisnis penggemukan sapi potong di Indonesia. Bisnis penggemukan sapi potong berkaitan erat dengan investasi dalam jumlah yang cukup besar. Untuk itu, penilaian kelayakan investasi perlu dilakukan agar terhindar dari keterlanjuran investasi yang tidak menguntungkan.
Penilaian kelayakan investasi pada bisnis penggemukan sapi potong dilihat dari dua aspek yaitu aspek nonfinansial berupa aspek pasar, aspek teknis, aspek manajemen dan hukum, dan aspek sosial, ekonomi, dan lingkungan, dan aspek finansial. Analisis kelayakan aspek nonfinansial akan melihat bagaimana kondisi bisnis penggemukan sapi potong mampu memenuhi kriteria dari masing-masing aspek kelayakan nonfinansial, mulai dari potensi pasar yang dapat diraih, kegiatan produksi yang dilakukan, kegiatan manajerial dalam masa pembangunan bisnis hingga bisnis dijalankan, serta dampak atau manfaat dari bisnis penggemukan sapi potong dilihat dari sisi sosial, ekonomi, dan lingkungan.

Bisnis penggemukan sapi potong tentu dihadapkan pada ketidakpastian yang memungkinkan terjadinya perubahan-perubahan yang akan mempengaruhi kelayakan bisnis, seperti penurunan volume penjualan sapi siap potong dan peningkatan biaya pakan konsentrat. Analisis sensitivitas berdasarkan switching value dilakukan untuk mengetahui sensitivitas (kepekaan) dari komponen yang kemungkinan mengalami perubahan selama bisnis dilakukan.

Berdasarkan uraian tersebut, maka masalah penelitian yang diangkat dalam penelitian ini adalah bagaimana kelayakan investasi dan sensitivitas bisnis penggemukan sapi potong, baik berdasarkan aspek finansial maupun nonfinansial?. Adapun tujuan dari penelitian ini adalah untuk mengetahui kelayakan investasi dan sensitivitas bisnis penggemukan sapi potong, baik dari aspek finansial maupun nonfinansial. 


\section{METODE PENELITIAN}

Penelitian dilakukan pada bulan Januari hingga April 2013. Lokasi penelitian dilaksanakan di PT Catur Mitra Taruma (TARUMA) yang berkantor pusat di Grha Induk KUD Lantai 3, Warung Buncit Raya No. 18-20, Jakarta 12510, dan kandang penggemukan sapi yang terletak di Jl. Raya Jonggol Cariu km 81, Desa Cariu, Kecamatan Cariu, Kabupaten Bogor, Jawa Barat. Pemilihan lokasi ini dilakukan secara sengaja (purposive) dengan mempertimbangkan bahwa TARUMA merupakan perusahaan penggemukan sapi potong di kawasan Jabodetabek sebagai kawasan pasar utama industri penggemukan sapi potong (Talib dan Noor, 2008) dengan umur operasional yang masih sangat muda, yaitu 3 tahun dan nilai dari kegiatan investasi dan operasional yang dilakukan oleh TARUMA cukup besar, mencapai Rp 30 milyar dan Rp 87,5 milyar serta melakukan pinjaman modal kerja kepada pihak perbankan.

Jenis data yang digunakan dalam penelitian ini adalah data produksi berupa data penggunaan input termasuk jumlah dan keseluruhan biaya yang dikeluarkan serta data penerimaan (penjualan output). Data yang digunakan dalam penelitian ini berasal dari dua sumber yaitu sumber primer dan sumber sekunder. Data dari sumber primer diperoleh langsung dari TARUMA melalui wawancara kepada direktur utama, pihak manajer, dan karyawan lapang. Data dari sumber sekunder pada penelitian ini diperoleh dari dokumen yang dimiliki oleh TARUMA seperti company profile TARUMA, laporan keuangan, studi kepustakaan, dan penelusuran literatur Badan Pusat Statistik (BPS), Kementrian Pertanian, Direktorat Jenderal Peternakan dan Kesehatan Hewan, Badan Ketahanan Pangan serta penelitian terdahulu yang berkaitan dengan penelitian ini.

Pengolahan dan analisis data yang digunakan dalam penelitian ini menggunakan metode analisis kualitatif dan kuantitatif sesuai dengan sifat data. Data yang bersifat kualitatif dianalisis untuk mengkaji aspek kelayakan non-finansial yaitu aspek pasar, aspek teknis, aspek manajemen dan hukum, aspek sosial, ekonomi, dan lingkungan. Data yang bersifat kuantitatif diolah untuk mengkaji aspek kelayakan finansial berdasarkan kriteria penilaian investasi yaitu NPV, Net B/C, IRR, dan PP serta dilakukan analisis sensitivitas melalui switching value untuk mengetahui komponen dalam bisnis penggemukan sapi potong yang lebih peka terhadap perubahan serta mengetahui persentase perubahan produksi dan biaya variabel terhadap kelayakan finansial yang masih dapat ditoleransi dalam bisnis sehingga masih dinyatakan layak dengan menggunakan Microsoft Excel 2007 dan kalkulator.

Analisis yang dilakukan untuk menilai kelayakan bisnis penggemukan sapi potong adalah sebagai berikut:

\section{Analisis Aspek Pasar}

Tujuan analisis aspek pasar yang dilakukan pada bisnis penggemukan sapi potong adalah untuk menilai apakah bisnis penggemukan sapi potong yang dijalankan dapat menghasilkan produk yang diterima oleh pasar dan menguntungkan. Bisnis penggemukan sapi 
potong dinyatakan layak berdasarkan aspek pasar jika bisnis tersebut telah memenuhi beberapa kriteria yang diperlukan dalam aspek pasar seperti potensi dan pangsa pasar yang jelas, bauran pemasaran yang baik serta produk yang dihasilkan dapat diterima oleh pasar dan menguntungkan (Kasmir dan Jakfar, 2010; Suliyanto, 2010).

\section{Analisis Aspek Teknis}

Tujuan analisis aspek teknis yang dilakukan pada bisnis penggemukan sapi potong adalah untuk menilai apakah secara teknis bisnis penggemukan sapi potong dapat dijalankan dengan baik atau tidak. Kriteria yang diperhatikan dalam penilaian aspek teknis adalah kegiatan penentuan lokasi bisnis, tata letak atau layout produksi, proses produksi serta penggunaan infrastruktur dan fasilitas yang ada. Bisnis penggemukan sapi potong dinyatakan layak berdasarkan aspek teknis jika bisnis tersebut telah memenuhi kriteria yang ada pada aspek teknis serta mampu menjawab tujuan dari analisis aspek teknis yang dilakukan (Kasmir dan Jakfar, 2010; Suliyanto, 2010).

\section{Analisis Aspek Manajemen dan Hukum}

Tujuan analisis aspek manajemen yang dilakukan pada bisnis penggemukan sapi potong adalah untuk menilai apakah bisnis yang dijalankan dapat dibangun sesuai dengan rencana dan apakah tersedia sumber daya manusia yang sesuai dengan kegiatan bisnis yang dijalankan. Kriteria yang harus ada dalam penilaian aspek manajemen adalah kegiatan manajerial pada masa pembangunan bisnis dan kegiatan manajerial pada masa operasional bisnis. Bisnis penggemukan sapi potong dinyatakan layak berdasarkan aspek manajemen jika bisnis tersebut telah memenuhi kriteria yang ada pada aspek manajemen serta mampu menjawab tujuan dari dilakukannya analisis aspek manajemen (Kasmir dan Jakfar, 2010; Suliyanto, 2010).

Tujuan analisis aspek hukum yang dilakukan pada bisnis penggemukan sapi potong adalah untuk menilai apakah bisnis yang dijalankan memenuhi ketentuan hukum dan berbagai perizinan yang diperlukan dalam rangka pendirian dan operasional perusahaan. Kriteria yang dilihat dalam analisis kelayakan aspek hukum adalah kelengkapan dokumen serta perizinan. Bisnis penggemukan sapi potong dinyatakan layak berdasarkan aspek hukum jika bisnis tersebut telah memenuhi kriteria yang ada pada aspek hukum serta mampu menjawab tujuan dari dilakukannya analisis aspek hukum (Kasmir dan Jakfar, 2010; Suliyanto, 2010).

\section{Analisis Aspek Sosial, Ekonomi, dan Lingkungan}

Tujuan analisis aspek sosial, ekonomi, dan lingkungan yang dilakukan pada bisnis penggemukan sapi potong adalah untuk menilai apakah bisnis yang dijalankan dapat memberikan manfaat baik dilihat dari sisi sosial, ekonomi, maupun lingkungan. Bisnis penggemukan sapi potong dinyatakan layak berdasarkan aspek sosial, ekonomi, dan lingkungan jika bisnis tersebut mampu 
memberikan manfaat secara sosial, ekonomi, dan lingkungan baik bagi masyarakat sekitar lokasi bisnis maupun pemerintah (Kasmir dan Jakfar, 2010).

\section{Analisis Aspek Finansial}

\section{a) Net Present Value (NPV)}

Net present value (NPV) merupakan nilai selisih antara total present value manfaat dengan total present value biaya atau penjumlahan dari present value manfaat bersih selama umur bisnis (Nurmalina et al., 2010). NPV menunjukkan manfaat bersih yang di-terima oleh perusahaan selama umur bisnis pada discount rate tertentu. Satuan dari NPV adalah Rupiah. Suatu bisnis dikatakan layak jika nilai NPV-nya lebih besar dari nol, sedangkan bisnis yang nilai NPV-nya kurang dari nol maka dikatakan bisnis tersebut tidak layak. Secara matematis, NPV dirumuskan sebagai berikut:

$$
\mathrm{NPV}=\sum_{t=1}^{n} \frac{B t-C t}{(1+i)^{t}}
$$

\footnotetext{
Dimana:

$\mathrm{Bt}=$ Manfaat pada tahun $\mathrm{t}$

$\mathrm{Ct}=$ Biaya pada tahun $\mathrm{t}$

$\mathrm{t}=$ Tahun kegiatan bisnis

$i \quad=$ Tingkat discount rate (\%)
}

\section{b) Net Benefit-Cost Ratio (Net B/C)}

Net benefit-cost ratio (Net B/C) merupakan salah satu kriteria penilaian investasi untuk menggambarkan manfaat bersih yang menguntungkan terhadap setiap satu satuan kerugian dari bisnis tersebut (Nurmalina et al., 2010). Suatu bisnis dikatakan layak jika nilai Net B/C nya lebih dari satu, sedangkan jika nilai Net B/C -nya kurang dari satu maka bisnis tersebut dikatakan tidak layak. Secara matematis, Net B/C dirumuskan sebagai berikut:

$$
N e t \frac{B}{C}=\frac{\sum_{t=1}^{n} \frac{B t-C t}{(1+i) t}}{\sum_{t=1}^{n} \frac{B t-C t}{(1+i)^{t}}} \cdots \frac{(\text { untuk } B t-C t>0)}{(\text { untukBt-Ct<0) }}
$$

$$
\begin{aligned}
& \text { Dimana: } \\
& \mathrm{Bt}=\text { Manfaat pada tahun } \mathrm{t} \\
& \mathrm{Ct}=\text { Biaya pada tahun } \mathrm{t} \\
& \mathrm{t} \quad=\text { Tahun kegiatan bisnis } \\
& \mathrm{i} \quad=\text { Tingkat discount rate }(\%)
\end{aligned}
$$

\section{c) Internal Rate of Return (IRR)}

Internal Rate of Return (IRR) merupakan kriteria penilaian investasi untuk melihat besarnya pengembalian bisnis terhadap investasi yang dilakukan (Nurmalina et al., 2010). Sebuah bisnis dikatakan layak jika nilai IRR lebih besar dari nilai discount rate-nya. IRR dinyatakan dengan satuan persentase (\%). Secara matematis, IRR dirumuskan sebagai berikut:

$$
\mathrm{IRR}=i_{1}+\frac{\mathrm{NPV}_{1}}{\mathrm{NPV}_{1}-\mathrm{NPV}_{2}} \times\left(i_{2}-i_{1}\right)
$$

Dimana:

$\mathrm{NPV}_{1}=\mathrm{NPV}$ positif

$\mathrm{NPV}_{2}=\mathrm{NPV}$ negatif

$i_{1} \quad=$ discount rate yang menghasilkan NPV positif

$i_{1} \quad=$ discount rate yang menghasilkan NPV negatif

IRR adalah tingkat discount rate yang menghasilkan NPV sama dengan nol, artinya besarnya persentase IRR dalam kriteria penilaian investasi bisnis tertentu merupakan persentase discount rate pada saat NPV menunjukkan angka nol (Nurmalina et al., 2010).

\section{d) Payback Period}

Payback period (PP) merupakan kriteria penilaian investasi yang digunakan untuk mengukur seberapa 
cepat kegiatan investasi yang dilakukan dalam suatu bisnis dapat kembali (Nurmalina et al, 2010). Suatu bisnis dapat dikatakan layak jika payback period-nya lebih kecil dari umur bisnis yang dijalankan. Satuan dari payback period adalah tahun. Secara matematis, payback period dirumuskan sebagai berikut:

$$
\text { Payback Period }=\frac{\mathrm{I}}{\mathrm{Ab}}
$$

Dimana:

I = Biaya investasi yang dikeluarkan

$\mathrm{Ab}=$ Manfaat bersih yang diperoleh setiap tahunnya

\section{Asumsi Dasar}

Beberapa asumsi dasar yang digunakan dalam penelitian ini adalah sebagai berikut:

1. Umur bisnis untuk analisis finansial selama 21 tahun, berdasarkan umur ekonomis dari bangunan kandang sapi yaitu 20 tahun yang dihitung sejak bangunan kandang selesai dibangun, yakni pada tahun kedua. Diasumsikan pada tahun pertama kegiatan bisnis dilakukan di kandang sewaan.

2. Sapi yang digemukkan adalah jenis-jenis sapi lokal dan sapi impor jenis BX (Brahman Cross). Sapi lokal yang dimaksud di sini adalah sapi Peranakan Ongole, Peranakan Limousin, Rotte Ongole, Sumba Ongole, dan Pegon yang diperoleh dari peternak di beberapa daerah di Pulau Jawa dan Sumbawa, sedangkan sapi BX diperoleh dari importir sapi Australia.
3. Kandang untuk sapi dibedakan menjadi dua yaitu kandang untuk sapi lokal dengan kapasitas maksimum 800 ekor sapi dan kandang untuk sapi BX dengan kapasitas maksimum 2400 ekor sapi. Kapasitas kandang sewaan sebesar 1800 ekor sapi, hanya digunakan pada tahun pertama.

4. Baik sapi lokal maupun sapi BX digemukkan selama 120 hari (4 bulan) dengan bobot awal untuk sapi lokal sebesar 331,40 kg dan bobot awal untuk sapi BX sebesar 301,30 kg, yang diperoleh berdasarkan rata-rata bobot awal sapi dari data sapi tahun 2011 dan tahun 2012 yang digemukkan di TARUMA.

5. Total bobot akhir dari sapi yang siap dijual dihitung menggunakan rumus:

Total Bobot Akhir (kg) = (jumlah sapi (ekor) x bobot awal $(\mathrm{kg}))+($ jumlah sapi (ekor) $\mathrm{x}$ $A D G$ (kg/ekor/hari) $\mathrm{x}$ lama penggemukan (hari))

Sehingga pada saat penjualan, bobot akhir dari sapi lokal sebesar 464,60 kg dan bobot akhir dari sapi BX sebesar 470,50 kg.

6. ADG (Average Daily Gain) merupakan rataan pertambahan bobot sapi setiap hari, satuannya kg/ekor/hari. ADG untuk sapi lokal yang digemukkan di TARUMA adalah 1,11 kg/ekor/hari, sedangkan ADG untuk sapi BX adalah 1,41 kg/ekor/hari. Angka ADG tersebut diperoleh dari data sapi tahun 
2011 dan tahun 2012 yang digemukkan di TARUMA.

7. Proyeksi yang dilakukan tidak memperhatikan tahapan siklus bisnis, artinya bisnis yang dijalankan stabil dan berada pada kondisi kemampuan produksi maksimumnya.

8. Tingkat mortalitas dari sapi yang digemukkan diasumsikan sebesar 0,05 persen setiap tahunnya baik untuk sapi lokal maupun sapi BX. Persentase tingkat mortalitas diperoleh berdasarkan data historis TARUMA.

9. Biaya pengangkutan sapi hanya dikeluarkan pada saat pembelian sapi lokal dan hanya 7 persen dari total keseluruhan sapi yang dibeli dalam satu tahun yang mengeluarkan biaya pengangkutan, sebesar Rp 561,728/kg bobot sapi, sisanya tidak ada biaya pengangkutan. Pada saat penjualan sapi siap potong tidak ada biaya pengangkutan karena ditanggung langsung oleh pembeli.

10.Perhitungan penyusutan menggunakan metode garis lurus, yaitu:

Penyusutan per tahun $=$

$$
\frac{\text { Nilai Beli - Nilai Sisa }}{\text { Umur Ekonomis }}
$$

11. Tingkat discount rate (DR) yang digunakan adalah sebesar 13 persen berdasarkan besarnya suku bunga pinjaman pada Victoria Bank, selaku bank yang memberikan pinjaman modal kerja untuk TARUMA, diasumsikan tetap hingga akhir bisnis.
12.Pajak pendapatan yang digunakan berdasarkan Undang-Undang Republik Indonesia Nomor 36 tahun 2008, pasal 17 ayat 2 a, yang merupakan perubahan keempat atas Undang-Undang Nomor 7 tahun 1983 tentang pajak penghasilan yaitu sebesar 25 persen, berlaku flat hingga akhir bisnis.

\section{HASIL DAN PEMBAHASAN}

\section{Analisis Kelayakan Aspek Pasar}

Hasil analisis aspek pasar menunjukkan bahwa bisnis penggemukan sapi potong pada TARUMA layak untuk dijalankan, karena telah memenuhi kriteria kelayakan bisnis yang ada yaitu potensi dan pangsa pasar yang jelas, bauran pemasaran yang dijalankan dengan baik serta produk yang dihasilkan dapat diterima oleh pasar dan menguntungkan. TARUMA telah memiliki target pasar dan pangsa pasar yang jelas dalam memasarkan sapi siap potong yang dihasilkan TARUMA. Selain itu, potensi pasar pada masa yang akan datang yang masih terbuka lebar seiring dengan peningkatan konsumsi yang dipengaruhi oleh peningkatan jumlah penduduk dan peningkatan pendapatan. Strategi pemasaran melalui bauran pemasaran juga telah diupayakan dengan baik. Produk yang dihasilkan TARUMA merupakan produk yang diinginkan konsumen dengan kualitas yang baik serta harga sesuai dengan harga yang berlaku di pasaran. Konsumen langsung memilih sapi mana yang akan dibeli dengan datang langsung ke lokasi penggemukan TARUMA sehingga konsumen dapat 
memastikan sendiri kondisi sapi yang akan dibeli. Selain produknya dapat diterima pasar, produk yang dihasilkan TARUMA merupakan produk yang menguntungkan untuk dijual. Keuntungan tersebut diperoleh dari pertambahan bobot sapi selama kegiatan penggemukan dijalankan.

\section{Analisis Kelayakan Aspek Teknis}

Hasil analisis aspek teknis menunjukkan bahwa bisnis penggemukan sapi potong pada TARUMA layak untuk dijalankan karena telah memenuhi kriteria kelayakan bisnis yang ada yaitu penentuan lokasi bisnis yang tepat, pemanfaatan infrastruktur dan fasilitas yang ada, proses produksi yang jelas, dan tata letak atau layout produksi yang baik. Lokasi bisnis dipilih berdasarkan alasan kedekatan dengan konsumen, sumber daya alam yang tersedia mendukung untuk kegiatan bisnis penggemukan sapi potong serta faktor ketersediaan tenaga kerja. Proses produksi telah dijalankan dengan baik mulai dari pembelian sapi bakalan hingga proses penjualan dilakukan. TARUMA menyiapkan persyaratan dan standar tertentu pada setiap kegiatan produksi yang dijalankan sehingga hasil dari kegiatan produksinya dapat memuaskan. Infrastruktur dan fasilitas telah dibangun dengan lengkap guna menunjang kegiatan produksi yang dijalankan TARUMA. Infrastruktur dan fasilitas yang ada ditata sedemikian rupa sehingga menghasilkan layout produksi yang baik dan efisien serta mempermudah proses produksi yang dilakukan.
Proses produksi yang dijalankan TARUMA dilakukan dengan prosedur yang lengkap yang telah ditentukan oleh pihak manajemen TARUMA, mulai dari aktivitas pembelian sapi bakalan, pemasukan dan pengelompokkan sapi bakalan di kandang, pemeliharaan sapi bakalan yang meliputi pemberian pakan, pengecekan kesehatan, dan pembersihan kandang, hingga pemanenan sapi siap jual. Keseluruhan proses produksi tersebut diupayakan dengan sangat baik sehingga tingkat mortalitas (kematian) dari sapi yang digemukkan di TARUMA dapat diminimalisir, hanya sebesar 0,05 persen per tahunnya.

\section{Analisis Kelayakan Aspek Manajemen dan Hukum}

Hasil analisis aspek manajemen menunjukkan bahwa bisnis penggemukan sapi potong pada TARUMA layak untuk dijalankan karena telah memenuhi kriteria kelayakan bisnis yang ada yaitu kegiatan manajerial pada masa pembangunan bisnis dan pada masa operasional bisnis yang dijalankan dengan baik. Bisnis penggemukan sapi potong pada TARUMA telah dibangun sesuai dengan rencana yang telah ditentukan sebelumnya. Sumberdaya manusia yang baik juga dimiliki oleh TARUMA sehingga mampu menghasilkan kegiatan manajerial yang baik, baik dalam masa pembangunan bisnis maupun pada masa operasional bisnis. Struktur organisasi yang ada mencerminkan kegiatan manajerial yang baik yaitu struktur organisasi dibagi-bagi berdasarkan dengan sub bidang masingmasing, mulai dari bidang pemasaran 
(niaga), bidang produksi (kegiatan penggemukan), serta bidang administrasi dan keuangan. Deskripsi dari masingmasing pekerjaan yang ada juga telah ditentukan degan jelas sehingga masingmasing individu dalam organisasi perusahaan mampu menjalankan tugas dan tanggung jawabnya dengan baik.

Hasil analisis aspek hukum menunjukkan bisnis penggemukan sapi potong pada TARUMA layak untuk dijalankan karena telah memenuhi kriteria kelayakan bisnis yang ada yaitu kelengkapan dokumen dan perizinan yang dilakukan, baik dalam masa pendirian bisnis hingga masa operasional bisnis. TARUMA dalam pendirian bisnisnya telah melengkapi berbagai dokumen dan kebutuhan perizinan yang ada, mulai dari akta pendirian PT, NPWP, tanda daftar perusahaan, pengesahan badan hukum perseroan, SIUP, izin lokasi, IMB, izin gangguan serta izin budidaya ternak.

\section{Analisis Kelayakan Bisnis Aspek Sosial, Ekonomi, dan Lingkungan}

Hasil analisis aspek sosial, ekonomi, dan lingkungan menunjukkan bahwa bisnis penggemukan sapi potong pada TARUMA layak untuk dijalankan karena telah memenuhi kriteria kelayakan bisnis yaitu baik secara sosial, ekonomi, maupun lingkungan kegiatan yang diusahakan TARUMA mampu mendatangkan manfaat tidak hanya bagi TARUMA sendiri juga manfaat bagi masyarakat sekitar dan pemerintah setempat. Manfaat yang muncul dari kegiatan bisnis penggemukan sapi potong yang dijalankan TARUMA berupa peluang peningkatan kesempatan kerja bagi masyarakat sekitar lokasi pendapatan, peningkatan pendapatan baik bagi masyarakat sekitar maupun bagi pemerintah daerah, serta pemanfaatan limbah untuk kegiatan pertanian masyarakat sekitar. Bisnis penggemukan sapi potong pada TARUMA juga dinilai tidak mencemari lingkungan karena TARUMA telah mengupayakan kegiatan pengolahan limbah yang dihasilkan dari kegiatan produksi yang dijalankan.

\section{Analisis Kelayakan Aspek Finansial}

Kriteria penilaian investasi digunakan untuk menganalisis kelayakan bisnis penggemukan sapi potong pada TARUMA berdasarkan aspek finansial. Hasil analisis berdasarkan laporan arus kas (cashflow) menunjukkan bahwa bisnis penggemukan sapi potong TARUMA layak secara finansial untuk dijalankan karena memiliki NPV lebih dari nol, nilai Net B/C lebih dari satu, IRR lebih dari discout rate yang digunakan (13\%), dan PP sebelum umur bisnis berakhir. Hasil analisis kelayakan finansial berdasarkan kriteria penilaian investasi disajikan pada Tabel 1.

\begin{tabular}{cc}
$\begin{array}{c}\text { Tabel 1. Hasil } \\
\text { finansial TARUMA }\end{array}$ & $\begin{array}{c}\text { analisis } \\
\text { kelayakan }\end{array}$ \\
\hline $\begin{array}{c}\text { Kriteria } \\
\text { kelayakan }\end{array}$ & Hasil penilaian pada \\
DF 13\%
\end{tabular}

Sumber: Data primer (diolah). 
NPV yang diperoleh selama umur bisnis sebesar Rp 20.696.240.936 menunjukkan bahwa pengusahaan TARUMA menurut nilai sekarang menguntungkan untuk dijalankan karena memberikan tambahan manfaat bersih sebesar Rp 20.696.240.936 selama jangka waktu 21 tahun. Nilai net B/C sebesar 1,75 menunjukkan bahwa setiap tambahan biaya yang dikeluarkan sebesar Rp 1 akan menghasilkan tambahan manfaat bersih bagi TARUMA sebesar Rp 1,75. Nilai IRR yang diperoleh yaitu 22 persen lebih besar dari tingkat diskonto yang digunakan yaitu 13 persen. Persentase IRR menunjukkan seberapa besar pengembalian bisnis terhadap investasi yang ditanamkan. PP yang diperoleh selama 7 tahun 3 bulan menunjukkan bahwa jangka waktu pengembalian investasi yang dilakukan lebih cepat dari umur bisnis.

Selain analisis aspek finansial berdasarkan kriteria penilaian investasi, juga dilakukan analisis laba rugi pada TARUMA. Laporan laba rugi menggambarkan kinerja perusahaan dalam periode tertentu karena dalam laporan laba rugi dapat dilihat kondisi keuntungan yang diperoleh perusahaan pada periode tertentu. Laba bersih positif pertama yang diperoleh TARUMA terjadi pada tahun kedua berdirinya bisnis, yaitu sebesar Rp 2.889.607.652. Namun pada tahun berikutnya laba negatif kembali diperoleh. Laba positif yang diperoleh TARUMA pada tahun kedua diperkirakan karena jumlah pembelian sapi yang sedikit pada tahun tersebut namun nilai penjualan sapinya besar. Nilai penjualan yang lebih besar tersebut diperoleh dari penjualan persediaan sapi yang dibeli di tahun pertama namun dijual pada tahun kedua. Penyebab laba negatif yang diperoleh TARUMA pada masa awal bisnisnya adalah kapasitas produksi maksimal yang belum terpenuhi. Terbukti pada saat kapasitas produksi telah dimaksimalkan pada tahun 2014 diperoleh laba positif sebesar Rp10.931.729.927 (Lampiran 1).

Analisis switching value digunakan untuk mengetahui batasan persentase perubahan tertentu pada komponen penting dari bisnis yang dijalankan. Komponen dari bisnis penggemukan sapi pada TARUMA yang dinilai peka terhadap perubahan adalah penurunan volume penjualan sapi siap potong dan peningkatan biaya pakan konsentrat. Berdasarkan besaran persentase perubahan yang diperoleh dari analisis switching value, maka dapat diketahui komponen mana yang lebih peka terhadap perubahan, dilihat berdasarkan besaran persentase perubahan. Besaran persentase perubahan yang rendah mengindikasikan bahwa komponen tersebut relatif lebih peka jika dibandingkan dengan komponen lain yang besaran persentase perubahannya lebih besar. Hasil analisis switching value yang diperoleh disajikan pada Tabel 2.

Tabel 2. Hasil analisis switching value pada TARUMA

\begin{tabular}{lr}
\hline \multicolumn{1}{c}{$\begin{array}{c}\text { Komponen yang } \\
\text { berubah }\end{array}$} & $\begin{array}{c}\text { Persentase } \\
\text { perubahan }\end{array}$ \\
\hline $\begin{array}{l}\text { Maksimum penurunan } \\
\text { volume penjualan sapi }\end{array}$ & $2,99 \%$ \\
$\begin{array}{l}\text { siap potong } \\
\text { Maksimum peningkatan } \\
\text { biaya pakan konsentrat }\end{array}$ & $15,72 \%$ \\
Sumber: Data primer (diolah) &
\end{tabular}


Hasil analisis switching value yang diperoleh yang menunjukkan bahwa maksimum penurunan volume penjualan sapi siap potong yang masih dapat ditoleransi agar bisnis tetap dikatakan layak adalah sebesar 2,99 persen dan maksimum peningkatan biaya pakan konsentrat yang masih dapat ditoleransi agar bisnis tetap dikatakan layak adalah sebesar 15,72 persen. Pada kondisi tersebut, besarnya NPV yang diterima perusahaan adalah nol dengan nilai Net B/C sebesar 1 dan IRR sebesar 13 persen sesuai dengan discount rate yang digunakan. Jika dibandingkan besaran persentase maksimum antara penurunan volume penjualan sapi siap potong dan peningkatan biaya pakan konsentrat, besaran persentase maksimum penurunan volume penjualan sapi siap potong lebih rendah dibandingkan besaran persentase maksimum peningkatan biaya pakan konsentrat, sehingga dapat dikatakan bahwa pada TARUMA komponen penjualan sapi siap potong lebih peka terhadap perubahan dibandingkan dengan biaya pakan konsentrat. Komponen yang lebih peka terhadap perubahan tersebut hendaknya lebih diperhatikan oleh perusahaan sehingga perubahan yang terjadi tidak melebihi batasan yang ada karena jika melebihi batasan yang ada maka bisnis yang dijalankan akan mengalami kerugian dan bisnis tidak lagi dinyatakan layak untuk dijalankan.

Penurunan volume penjualan sapi siap potong pada harga jual yang konstan sebesar 2,99 persen atau setara dengan $132.273 \mathrm{~kg}$ bobot hidup untuk sapi BX dan $142.986 \mathrm{~kg}$ bobot hidup untuk sapi lokal. Jumlah tersebut apabila di- konversikan ke dalam jumlah sapi, maka penurunan volume penjualan sebesar 2,99 persen setara dengan penurunan penjualan sebanyak 281 ekor sapi BX atau 308 ekor sapi lokal.

Penurunan volume penjualan dapat terjadi setidaknya karena dua kemungkinan. Kemungkinan pertama adalah kemampuan perusahaan untuk berproduksi berkurang. Dalam hal ini, kemampuan berproduksi perusahaan dihubungkan dengan angka pertambahan bobot harian pada sapi yang digemukkan $(A D G)$. Apabila $A D G$ menurun, bobot akhir dari sapi yang digemukkan akan berkurang dari sebagaimana mestinya, sehingga akan berdampak pada penurunan volume penjualan. Penurunan $A D G$ dari sapi yang digemukkan dapat disebabkan oleh penurunan kondisi kesehatan sapi atau asupan gizi yang diperoleh sapi berkurang.

Kemungkinan kedua penyebab penurunan penjualan adalah berkaitan dengan strategi pemasaran. Strategi pemasaran berkaitan dengan bauran pemasaran perusahaan yang terdiri dari produk, harga, tempat, dan promosi. Penurunan kualitas produk dapat menurunkan volume penjualan. Selain itu, karena perusahaan bersaing dengan perusahaan lainnya, apabila harga jual tidak kompetitif dengan pesaingnya, maka dapat menurunkan volume penjualan. Terkait dengan tempat dan promosi, tidak ada masalah karena perusahaan berlokasi di kawasan pusat konsumsi daging sapi (Jabodetabek) dan perusahaan telah memiliki pelanggan tetap. 
Peningkatan biaya pakan konsentrat sebesar 15,72 persen atau setara dengan Rp 346/kg konsentrat dapat dimungkinkan terjadi karena peningkatan harga bahan baku pakan seperti misalnya harga kedelai atau bahan baku pakan lainnya.

\section{KESIMPULAN DAN SARAN}

\section{Kesimpulan}

Adapun kesimpulan yang didapatkan berdasarkan penelitian yang telah dilakukan adalah:

1. Berdasarkan hasil analisis kelayakan investasi aspek pasar, aspek teknis, aspek manajemen dan hukum, serta aspek sosial, ekonomi, dan lingkungan menunjukkan bahwa bisnis penggemukan sapi potong layak untuk dijalankan. Berdasarkan hasil analisis kelayakan investasi aspek finansial, bisnis penggemukan sapi potong juga layak untuk dijalankan, dilihat dari indikator kriteria penilaian investasi yang menunjukkan NPV mencapai Rp 20.696.240.936, Net B/C sebesar 1.75, IRR sebesar 22 persen, dan PP selama 7 tahun 3 bulan.

2. Hasil analisis switching value pada dua komponen yang dinilai paling berpengaruh dalam bisnis penggemukan sapi yaitu penjualan sapi siap potong dan biaya pakan menunjukkan bahwa penurunan maksimum yang masih dapat ditoleransi dalam volume penjualan sapi siap potong sebesar 2,99 persen sedangkan kenaikan maksimum yang masih dapat ditoleransi dalam biaya pakan sebesar 15,72 persen. Hasil tersebut menunjukkan bahwa komponen penjualan sapi siap potong lebih peka terhadap perubahan dibanding komponen biaya pakan.

\section{Saran}

Adapun saran yang dapat disampaikan adalah:

1. Upaya antisipasi terhadap penurunan penjualan sapi potong yang diakibatkan oleh penurunan $A D G$ adalah dengan terus memperhatikan manajemen pakan dan pengecekan kesehatan sapi potong, mengingat penurunan penjualan sapi potong merupakan komponen bisnis yang peka terhadap perubahan.

2. Antisipasi peningkatan harga bahan baku pakan misalnya kedelai atau bahan baku lainnya dapat dilakukan dengan menyiapkan alternatif bahan baku pakan lainnya yang memiliki kandungan serupa dengan bahan baku yang meningkat harganya dengan harga yang lebih murah sehingga kualitas pakan yang dihasilkan tidak jauh berbeda dengan kualitas pakan sebelumnya dan biaya yang dikeluarkan juga tidak mengalami peningkatan.

\section{UCAPAN TERIMA KASIH}

Terima kasih kami ucapkan kepada Biro Perencanaan dan Kerjasama Luar Negeri (BPKLN) Kementerian Pendidikan dan Kebudayaan Republik Indonesia yang telah memberikan beasiswa kepada penulis selama menempuh pendidikan master di Program Studi Magister Sains Agribisnis, Institut Pertanian Bogor. 


\section{DAFTAR PUSTAKA}

Ashari, N. Ilham dan S. Nuryanti. 2012. Dinamika Program Swasembada Daging Sapi: Reorientasi Konsepsi dan Implementasi. Analisis Kebijakan Pertanian, 10(2):181198.

Badan Koordinasi Penanaman Modal. 2012. Beef Cattle Industry at a Glance. Badan Koordinasi Penanaman Modal. Jakarta.

Daryanto, A. 2009. Dinamika Daya Saing Industri Peternakan. IPB Press. Bogor.

Direktorat Jenderal Peternakan dan Kesehatan Hewan. 2013. Statistik Peternakan dan Kesehatan Hewan 2013. Direktorat Jenderal Peternakan dan Kesehatan Hewan. Jakarta.

Ekowati, T., D.H. Darwanto, S. Nurtini dan A. Suryantini. 2011. The Analysis of Beef Cattle Subsystem Agribusiness Implementation in Central Java Province, Indonesia. J. Indonesian Trop. Anim. Agric, 36(4):281-289.

Hadi, P.U. dan N. Ilham. 2002. Problem dan Prospek Pengembangan Usaha Pembibitan Sapi Potong di Indonesia. Jurnal Litbang Pertanian, 21(4):148-157.

Ilham, N. 2009. Kelangkaan Produksi Daging: Indikasi dan Implikasi Kebijakannya. Analisis Kebijakan Pertanian, 7(1):43-63.

Kasmir dan Jakfar. 2010. Studi Kelayakan Bisnis Edisi Kedua. Kencana. Jakarta.
Kementerian Perdagangan. 2013. Peraturan Meneteri Perdagangan Republik Indonesia Nomor 46/MDAG/PER/8/2013. Kementerian Perdagangan. Jakarta.

Mayulu, H., Sunarso, C.I. Sutrisno, Sumarsono. 2010. Kebijakan Pengembangan Peternakan Sapi Potongdi Indonesia. Jurnal Litbang Pertanian, 29(1):34-41.

Ngadiyono, N. 2004. Pengembangan Sapi Potong dalam Rangka Penyediaan Daging di Indonesia. Pidato Pengukuhan Jabatan Guru Besar pada Fakultas Peternakan Universitas Gadjah Mada. UGM. Yogyakarta.

Nurmalina, R., T. Sarianti, A. Karyadi. 2010. Studi Kelayakan Bisnis. Departemen Agribisnis FEM IPB. Bogor.

Prasetyo, E., Sunarso, P.B. Santosa, E. Rianto. 2012. The Influence of Agribusiness Subsystem on Beef Cattle Fattening Farm's Profit in Central Java. J. Indonesian Trop. Anim. Agric, 37(2):121-126.

Priyanti, A., I. Mahendri, U. Kusnadi. 2011. Dinamika Produksi Daging Sapi di Wilayah Sentra Usaha Sapi Potong di Indonesia. Pusat Penelitian dan Pengembangan Peternakan dan Balai Penelitian Ternak. Bogor.

Priyanto, D. 2011. Strategi Pengembangan Usaha Ternak Sapi Potong dalam Mendukung Program Swasembada Daging Sapi dan Kerbau Tahun 2014. Jurnal Litbang Pertanian, 30(3):108-116. 
Pusat Data dan Sistem Informasi Pertanian. 2013a. Statistik Harga Komoditas Pertanian Tahun 2013. PusData dan Sistem Informasi Pertanian. Jakarta.

. 2013b. Buletin Konsumsi Pangan, 4(1):1-15.

Saragih, B. 2000. Agribisnis Berbasis Peternakan: Kumpulan Pemikiran. USESE Foundation dan Pusat Studi Pembangunan IPB. Bogor.

Suliyanto. 2010. Studi Kelayakan Bisnis: Pendekatan Praktis. Penerbit Andi. Yogyakarta.

Sunari, A., N. Avianto, M.N. Ritinov. 2010. Naskah Kebijakan: Strategi dan Kebijakan dalam Percepatan Pencapaian Swasembada Daging Sapi 2014. Direktorat Pangan dan Pertanian, BAPPENAS. Jakarta.
Suryana. 2009. Pengembangan Usaha Ternak Sapi Potong Berorientasi Agribisnis dengan Pola Kemitraan. Jurnal Litbang Pertanian, 28(1):2937.

Talib, C., Y.G. Noor. 2008. Penyediaan Daging Sapi Nasional dalam Ketahanan Pangan Indonesia. Prosiding Seminar Nasional Teknologi Peternakan dan Veteriner 2008. Puslitbangnak. Bogor. 


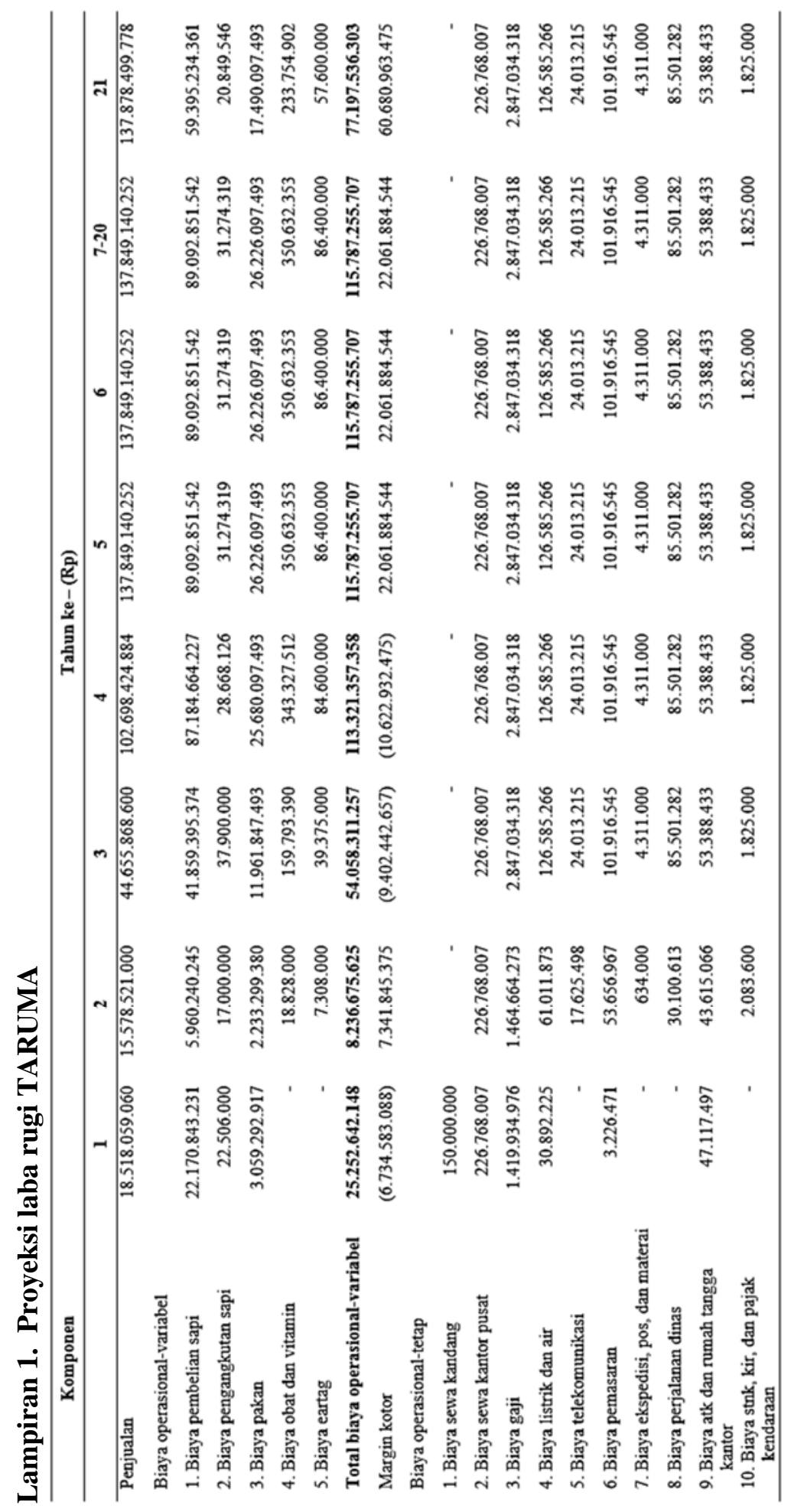




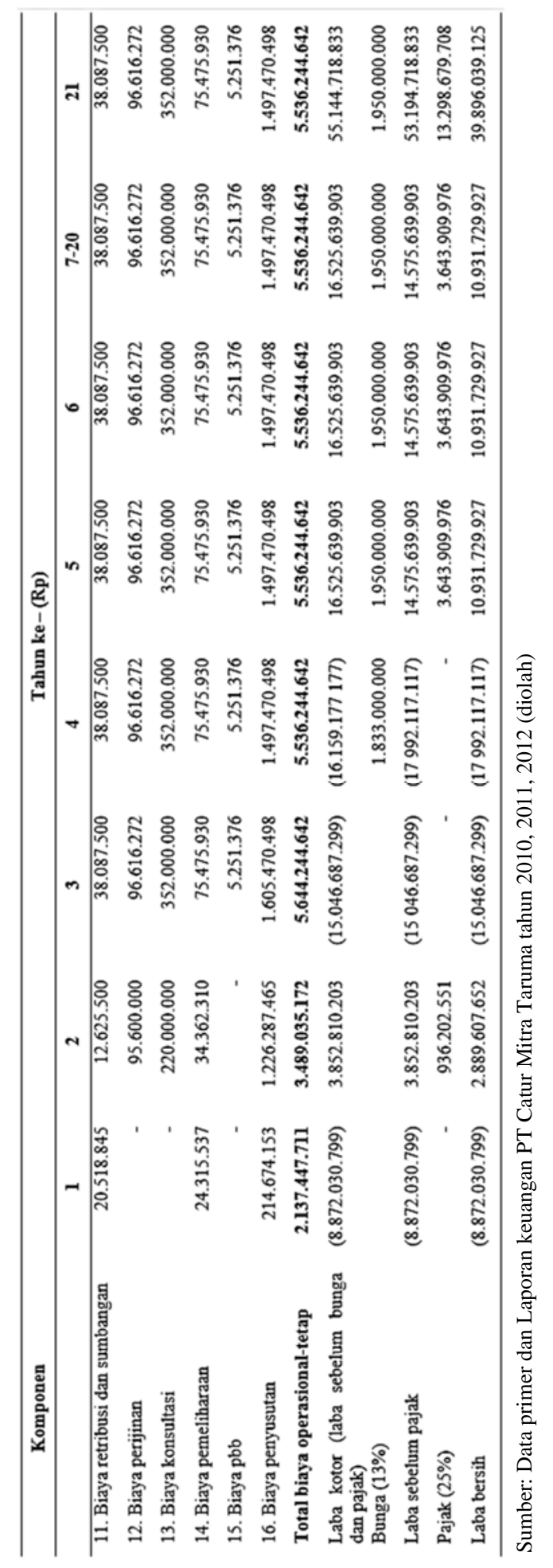


Chairun Nisa, Ratna Winandi dan Netti Tinaprilla 